\title{
Quantitative links between fluvial sediment discharge, trapped terrigenous flux and sediment accumulation, and implications for temporal and spatial distributions of sediment fluxes
}

\author{
Shih-Chieh $\mathrm{Hsu}^{\mathrm{a}, *}$, Shuh-Ji Kao ${ }^{\mathrm{a}, \mathrm{b}}$, Woei-Lih Jeng ${ }^{\mathrm{c}}$ \\ ${ }^{a}$ Research Center for Environmental Changes, Academia Sinica, Taipei, Taiwan, ROC \\ ${ }^{\mathrm{b}}$ Institude of Hydrological Sciences, National Central University, Taoyuan County, Taiwan, ROC \\ ${ }^{\mathrm{c}}$ Institute of Oceanography, National Taiwan University, Taipei, Taiwan, ROC
}

Received 1 April 2005; received in revised form 13 October 2005; accepted 21 October 2005

Available online 2 December 2005

\begin{abstract}
The southwestern-most Okinawa Trough (SOT), characterized by high sedimentation rates $(>0.1 \mathrm{~cm} / \mathrm{yr})$, has the potential for recording high-resolution episodic events, such as storm floods and seismic activities, at least on a regional scale. To retrieve data on past climate change from nearby sediment cores and quantitatively reconstruct it, particularly with respect to precipitation (or typhoon-induced flood events), a linkage between fluvial sediment discharge and terrigenous sediment flux is warranted. Apparent sediment fluxes, observed with four arrays of sediment traps deployed in the SOT, were found to vary with fluvial sediment discharges. Empirical equations for individual arrays of sediment traps are site-dependent and related to the scenario of initial supply, transport and final deposition of terrigenous sediments (i.e. land-sea interaction). Using these equations and hydrological data from 1950 to 2000, the long-term temporal and spatial variations of settling sediment fluxes were simulated. Simulation results agree well with sediment mass accumulation rates derived from literature data on ${ }^{210} \mathrm{~Pb}$ and ${ }^{137} \mathrm{Cs}$ chronology. The simulated spatial patterns of sediment fluxes along a slope-trough section illustrate that sediment plumes can disperse concurrently in two manners, namely near-bottom and mid-depth plumes, and the flood-driven plumes can travel very long distances, approaching $125^{\circ} \mathrm{E}$ or beyond. The sediment burial budget in the SOT was estimated to be approximately $5.2 \mathrm{Mt} / \mathrm{yr}$, representing about $80 \%$ of riverine exports from the Lanyang Hsi, Taiwan. This is the first study dealing qualitatively and quantitatively with two parameters, namely terrigenous sediment flux and fluvial sediment discharge.
\end{abstract}

(C) 2005 Elsevier Ltd. All rights reserved.

Keywords: Terrigenous sediment flux; Fluvial sediment discharge; Climate change; Okinawa Trough; Taiwan

\footnotetext{
*Corresponding author. Tel.: + $886226539885 \times 530$; fax: +886227833584 .

E-mail address: schsu815@rcec.sinica.edu.tw (S.-C. Hsu).
}

\section{Introduction}

The signatures of past environmental and climate changes can be extracted from sedimentary records in terms of the magnitude and fluctuation of sedimentation rate and the presence of specific sedimentary structures etc., particularly in the 
marginal seas with high sedimentation rates (Mulder et al., 2001, 2003; Huh et al., 2004; St-Onge et al., 2004). Terrigenous sediment supply is governed principally by climate conditions, such as precipitation, in addition to geological and tectonic settings (Milliman and Syvitski, 1992; Dadson et al., 2003; Chakrapani, 2005). Usually, a few external environmental forces, such as seismic activity, river floods or tsunamis which occur episodically, enhance sediment supply and change sedimentary structure (St-Onge et al., 2004; Hsu et al., 2004). Thus, the mass fluctuation of deposited terrigenous sediments and characteristic stratigraphic textures can be effective proxies of climate changes and environmental episodes (e.g. Schimmelmann et al., 1998; Perissoratis and Papadopoulos, 1999; Mulder et al., 2003; Huh et al., 2004). Nonetheless, sedimentary records can be applicable to unraveling these signatures only when the sedimentary processes are clarified and the specific sedimentary signatures, caused by different forces, can be differentiated. Also, another problem that must be addressed is how the sedimentary process and magnitude are scaled over time, and the linkage between them (i.e. sedimentary magnitude varying with time) requires verification, at least in documented history; otherwise the application of sedimentary records would be qualitative rather than quantitative.

In our previous study, we found a good correlation between marine sediment fluxes observed by sediment traps (hereafter referred to as trap fluxes) in the southwestern-most Okinawa Trough (SOT) and river runoff from the Lanyang Hsi, a river in eastern Taiwan (Fig. 1). Most elevated trap fluxes were supplied by fluvial exports occurring primarily during typhoon flood periods, while a few exceptional peak fluxes were due principally to large submarine earthquakes. A sophisticated schematic model has been proposed to describe the sediment sources and transport of the SOT. Recently, the results have been published in this journal (Hsu et al., 2004). The robust method established previously is used here to further examine the correlation between observed sediment fluxes and sediment discharges on the basis of the strong relationship between river runoff and sediment discharge formulated by Kao and Liu (2001). As a consequence, a striking finding was obtained and is reported in this paper in terms of transport mechanism and numerical relationship between contributor (i.e. river plume) and receptor (i.e. marine basin) for

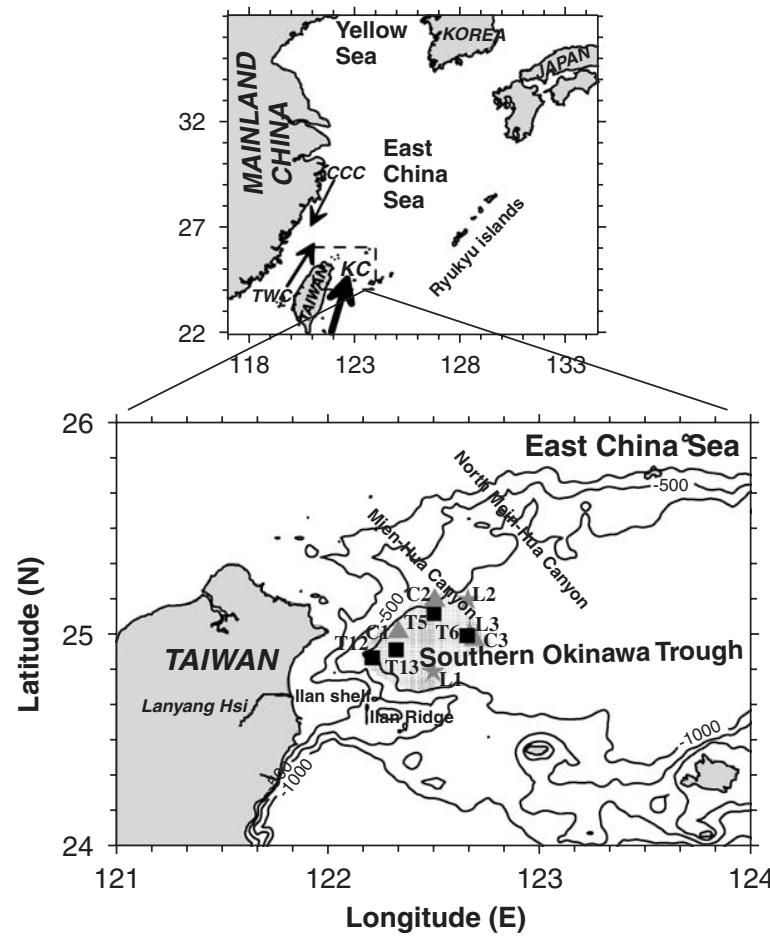

Fig. 1. Location map for four arrays of sediment traps (indicated by solid squares) deployed at the southwestern-most Okinawa Trough (SOT) with the East China Sea shelf to the north. The Lanyang Hsi, a river in eastern Taiwan, is the principal sediment source of the SOT. The Kuroshio Current (KC) prevailingly flows northward off eastern Taiwan, and a branch is generated owing to the collision of the main current with the impeding shelf and a part of it intruding onto the shelf. A region with high sedimentation rates, ranging from 0.25 to $0.52 \mathrm{~cm} / \mathrm{yr}$, is marked by a dotted, nearly square-shaped area, of ca. $2000 \mathrm{~km}^{2}$. Shown in the upper panel is a regional map, including two main flows, i.e. the Taiwan Warm Current (TWC) and China Coastal Current (CCC). Locations for ${ }^{210} \mathrm{~Pb}$ and ${ }^{137} \mathrm{Cs}$ chronological data taken from Chung and Chang (1995) (three stations C1-C3, labeled as gray triangles) and Lee et al. (2004) (three stations L1-L3, labeled as gray stars) are also indicated; details are given in Table 3. Note that three sites T6, C3 and L3 are located very close to one another.

trough sediments. When a few outliers in the scatter plots were found to be attributable to additional sediment supply by episodic, large submarine earthquakes, they were not taken into account. From the measured trap-flux data, the riverine signatures can be isolated, which are essentially dependent on precipitation combined with geological and tectonic settings (Milliman and Syvitski, 1992; Mulder and Syvitski, 1996; Dadson et al., 2003). Then, the result is interpreted as a full scenario regarding sediment fate, i.e. from contribution (source) to transportation to sedimentation (sink). This is the first 
example of a field study dealing qualitatively and quantitatively with two parameters, namely terrigenous sediment flux and fluvial sediment discharge. Moreover, with high sedimentation rates (usually higher than $0.1 \mathrm{~cm} / \mathrm{yr}$ ) in the SOT, this basin can be expected to record high time-resolution paleoclimatic and paleo-environmental changes, at least on a regional scale. Therefore, the study may imply the possibility that the paleoclimatic conditions, such as precipitation, can be unraveled from the fluctuation of sediment accumulation rates, since the link between the source and sink of terrigenous sediments in such a deep basin has already been quantitatively determined.

\section{Background}

Taiwan, a mountainous island, annually delivers tremendous amounts of sediment (up to $250 \mathrm{Mt}$ ) into the surrounding seas, of which a majority $(\sim 75 \%)$ is transported by river floods occurring primarily during a short typhoon period of extreme rainfall events (Kao and Liu, 2001; Milliman and Kao, 2005). On a global basis, it is recognized that sediments delivered to the ocean by medium- to small-size rivers, particularly in mountainous islands, account for approximately half the world total (Milliman and Syvitski, 1992). Because of the small size of the SOT, storm systems can induce elevated river discharges, which will also substantially affect the coastal ocean. River water and sediments are introduced into the ocean under the limited, oceanographic conditions (e.g. wind direction, stratification), which has important implications for sediment dispersal and the development of stratigraphy.

The study area, the southwestern-most part of the Okinawa Trough, off northeastern Taiwan, is characterized by rapid sedimentation rates $>0.1 \mathrm{~cm} / \mathrm{yr}$. Based on the result from a site $\left(24^{\circ} 48.24^{\prime} \mathrm{N}, 122^{\circ} 30.00^{\prime} \mathrm{E}\right)$ of ODP Leg 195 in the SOT, the sedimentation rate has been always high, reaching $325 \mathrm{~cm} / \mathrm{kyr}(0.325 \mathrm{~cm} / \mathrm{yr})$ since the late Holocene (http://www-odp.tamu.edu/publications/ pubs.htm), comparable with the short-term rate from ${ }^{210} \mathrm{~Pb}$ and ${ }^{137} \mathrm{Cs}$ chronology (Chung and Chang, 1995; Lee et al., 2004). The study area has the fastest sedimentation rate ever measured in a deep basin, such as the SOT, having a depth of more than $1500 \mathrm{~m}$. The buried and settling sediment in the SOT are composed predominantly of fine-grained aluminosilicate detritus, which is estimated to account for at least $80 \%$ of the total (Hsu et al., 2003, 2004; Hung et al., 2003). The sediment source is believed to be principally the Lanyang Hsi in northern Taiwan, together with other eastern Taiwanese rivers (Hsu et al., 1998, 2004; Jeng et al., 2003; Huh et al., 2004; Lee et al., 2004). On average, the Lanyang Hsi delivers $6.5-8.0 \mathrm{Mt}$ of sediment to the sea annually, equal to a normal rate of approximately $0.02 \mathrm{Mt} / \mathrm{d}$ (Kao and Liu, 2001; Water Resource Bureau, 1997), while the amount can vary over a wide range from 0.03 to $110 \mathrm{Mt} / \mathrm{yr}$, as estimated by Syvitski et al. (2005). Sediment burial in an area of approximately $2000 \mathrm{~km}^{2}$ with high sedimentation rates (ranging from 0.25 to $0.52 \mathrm{~cm} / \mathrm{yr}$, with an average of $0.36 \mathrm{~cm} / \mathrm{yr}$ ), as indicated in Fig. 1, is estimated to be approximately 6.3 Mt/yr (Hsu, 1998). Details on the background of the study area can be found in Hsu et al. (1998, 2003, 2004).

\section{Data acquisition and methods}

Four arrays of sediment traps $(n=11)$ were deployed in the SOT: station \#T12 located at the base of the northern slope of the Ilan Shelf and Ridge (ISR), station \#T13 at an intermediate site toward the central SOT, station \#T6 in the central part of the SOT, and station \#T5 at an offshore site, like station \#T6 but bounded on the north by the East China Sea slope (Fig. 1). The sediment fluxes were observed from these four arrays of sediment traps. Each array had traps at three depths, except for T6, which had only two (Table 1). Total deployment time covered nearly a 3-year period from May 1994 to January 1997. Details on sediment trap deployment and sediment flux data have been given elsewhere (Chung and Hung, 2000; Chung et al., 2003; Hsu et al., 2004). The original data set of hydrological observations from the Lanyang Hsi was taken from the Hydrological Yearbook published by the Water Resources Agency of Taiwan. In the study, however, data on daily sediment discharge from 1950 to 2000 were taken from Kao and Liu (2001), who applied a rating-curve method to compensate for the limited data on suspended-load concentration relative to water discharge. During the past 51 years, there were 50 days in which abnormal sediment discharge rates of up to $1 \mathrm{Mt}$ occurred and 23 days with rates of up to $2 \mathrm{Mt}$.

In our previous work, the relationship between trap flux and river runoff was studied by a 
Table 1

Regression equations of trapped sediment flux observed in the SOT and daily sediment discharge from the Lanyang Hsi (plots for the equations are displayed in Fig. 2)

\begin{tabular}{|c|c|c|c|}
\hline Depth (m) & Regression equation & Data number & $R^{2}$ \\
\hline \multicolumn{4}{|c|}{ Sediment trap array \#T12 (location: $24^{\circ} 53.37^{\prime} \mathrm{N}, 122^{\circ} 12.38^{\prime} \mathrm{E}$; bottom depth: $1017 \mathrm{~m}$ ) } \\
\hline 570 & $\begin{array}{l}\ln (Y)=0.49 \ln (X)-1.70 \\
\text { or } Y=e^{-1.79} X^{0.49}\end{array}$ & 12 & 0.70 \\
\hline 770 & $\begin{array}{l}\ln (Y)=0.23 \ln (X)+1.95 \\
\text { or } Y=e^{1.9} X^{0.23}\end{array}$ & 9 & 0.50 \\
\hline 970 & $\begin{array}{l}\ln (Y)=0.23 \ln (X)+1.75 \\
\text { or } Y=e^{1.75} X^{0.23}\end{array}$ & 12 & 0.45 \\
\hline \multicolumn{4}{|c|}{ Sediment trap array \#T13 (location: $24^{\circ} 55.36^{\prime} \mathrm{N}, 122^{\circ} 19.57^{\prime} \mathrm{E}$; bottom depth: $1392 \mathrm{~m}$ ) } \\
\hline 940 & $\begin{array}{l}\ln (Y)=0.19 \ln (X)+0.80 \\
\text { or } Y=e^{0.80} X^{0.19}\end{array}$ & 14 & 0.76 \\
\hline 1140 & $\begin{array}{l}\ln (Y)=0.20 \ln (X)+1.34 \\
\text { or } Y=e^{1.34} X^{0.20}\end{array}$ & 13 & 0.78 \\
\hline 1340 & $\begin{array}{l}\ln (Y)=0.20 \ln (X)+0.97 \\
\text { or } Y=e^{0.97} X^{0.20}\end{array}$ & 14 & 0.54 \\
\hline \multicolumn{4}{|c|}{ Sediment trap array \#T5 (location: $25^{\circ} 06.45^{\prime} \mathrm{N}, 122^{\circ} 30.06^{\prime} \mathrm{E}$; bottom depth: $1060 \mathrm{~m}$ ) } \\
\hline 560 & $\begin{array}{l}\ln (Y)=0.23 \ln (X)-0.84 \\
\text { or } Y=e^{-0.84} X^{0.23}\end{array}$ & 11 & 0.58 \\
\hline 760 & $\begin{array}{l}\ln (Y)=0.33 \ln (X)-1.25 \\
\text { or } Y=e^{-1.25} X^{0.33}\end{array}$ & 10 & 0.71 \\
\hline 960 & $\begin{array}{l}\ln (Y)=0.43 \ln (X)-1.67 \\
\text { or } Y=e^{-1.67} X^{0.43}\end{array}$ & 10 & 0.76 \\
\hline \multicolumn{4}{|c|}{ Sediment trap array \#T6 (location: $24^{\circ} 59.63^{\prime} \mathrm{N}, 122^{\circ} 39.26^{\prime} \mathrm{E}$; bottom depth: $1440 \mathrm{~m}$ ) } \\
\hline 740 & $\begin{array}{l}\ln (Y)=0.43 \ln (X)-2.48 \\
\text { or } Y=e^{-2.48} X^{0.43}\end{array}$ & 11 & 0.70 \\
\hline 1340 & $\begin{array}{l}\ln (Y)=0.42 \ln (X)-2.11 \\
\text { or } Y=e^{-2.11} X^{0.42}\end{array}$ & 11 & 0.62 \\
\hline
\end{tabular}

graph-matching method (Hsu et al., 2004). In the present study, regression analyses were performed to establish the relationship between the two parameters and to simulate (or predict) how marine sediment fluxes vary with diverse cases of river sediment discharges.

\section{Results and discussion}

\subsection{Quantitative relationships between trapped sediment flux and fluvial sediment discharge}

When temporal variations in both trap fluxes of the SOT and daily sediment discharges of the Lanyang Hsi were matched, different time lags (defined as the time required for river flood plumes to travel from the river mouth to the trap sites after heavy rainfall) had to be taken into account for each array of sediment traps. The stepwise procedures, described in our previous paper, were then followed: matching graphs (not shown, refer to Hsu et al., 2004) and examining the correlation between the two parameters. Different time lags were thus acquired: 3 days for \#T12, 5 days for \#T5 and \#T6, and 4 days for \#T13. As expected, there is a $\log -\log$ (i.e. power law) correlation between daily sediment discharge (in the unit of $\mathrm{t} / \mathrm{d}$ ) and observed sediment flux (in the unit of $\mathrm{g} / \mathrm{m}^{2} / \mathrm{d}$ ), in spite of several outliers deviating from the regression curves (Fig. 2). This indicates that terrigenous sediment fluxes are regulated primarily by fluvial sediment delivery, particularly during heavy rain periods (i.e. typhoon flood periods) and occasionally by other driving forces, such as (submarine) seismic activities occurring in the vicinity of the study area (Hsu et al., 2004). Surprisingly, these four arrays of sediment traps show several regression lines with varying slopes.

Curve-fitting equations were obtained as power equations for each regression line in individual 


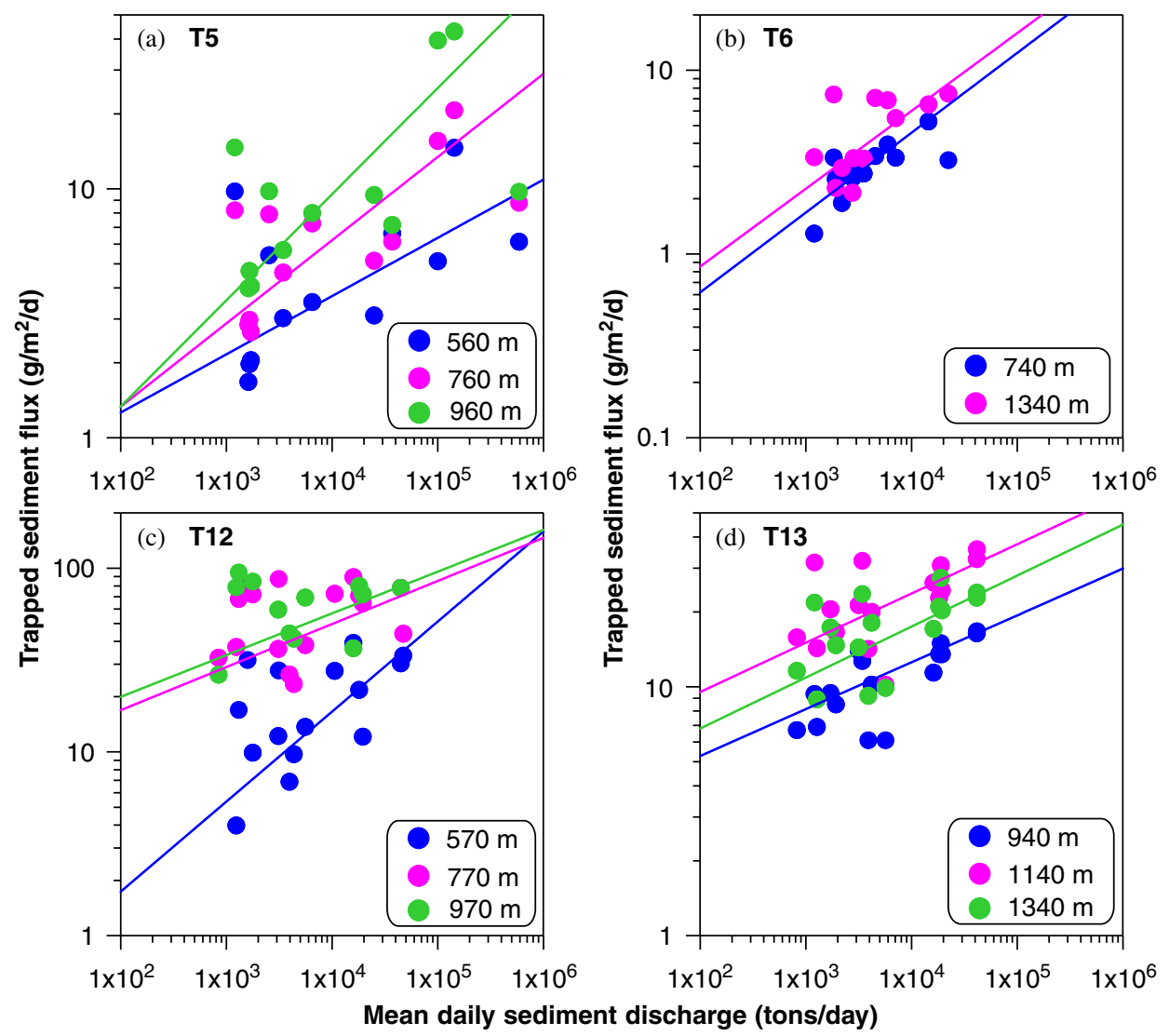

Fig. 2. Regression plots of observed sediment flux $\left(\mathrm{g} / \mathrm{m}^{2} / \mathrm{d}\right)$ versus daily sediment discharge ( $\left.\mathrm{t} / \mathrm{d}\right)$, derived from a rating-curve method for four arrays of sediment traps (stations \#T5, \#T6, \#T12 and \#T13), which have been shifted by a time lag from 3 to 5 days; see text for details. Note that the $x$ and $y$ axes are in log scale. Regression equations are summarized in Table 1.

$\log -\log$ scatter plots of daily sediment discharge versus trap flux (Fig. 2). Specific slopes and constants for individual regression lines of all studied sites, summarized in Table 1, may elucidate some important implications with regard to offshore transport and sedimentation of terrigenous sediments. Each case for the four arrays of sediment traps will be described, in the following order: \#T12, \#T13, \#T5 and \#T6, i.e. from the near-shore sites to the central basin. The station nearest to the ISR, \#T12, has a large slope (0.49) at the shallower depth $(570 \mathrm{~m})$, two-fold larger than the two almost parallel slopes (similarly 0.23) at the two other depths (770 and $970 \mathrm{~m}$ ). Moreover, this slope is the largest compared to the slopes of all other regression lines, indicating that the water above a depth of $\sim 600 \mathrm{~m}$ in the vicinity of the Lanyang Hsi river mouth (i.e. eastern Taiwan) is very sensitive to fluctuation of fluvial sediment exports relative to other locations. Another feature is that three regression lines cross at three points very close to one another, where the sediment discharge is $\sim 10^{6} \mathrm{t}$ (i.e. $1 \mathrm{Mt}$ ) per day (Fig. 2a). Note that on transect T12-T13-T6 (i.e. from the base of the ISR toward the central part of the SOT), the regression lines for two deeper traps (770 and $970 \mathrm{~m})$ at station \#T12 are nearly parallel with an equal slope (0.23). Similarly, station \#T13 has three almost parallel regression lines for its three traps, with approximately the same slopes $(0.19$ for $940 \mathrm{~m}$, and 0.20 for both the 1140- and 1340-m traps). Also, in the case of station \#T6, the regression lines are almost parallel, with nearly equal slopes $(0.42$ for the $740-\mathrm{m}$ and 0.43 for the $1340-\mathrm{m}$ traps). However, different regression equation constants were obtained for all regression lines of stations \#T12 and \#T13 with a similar slope $(\sim 0.20)$. In contrast to T12, T13 and T6, station \#T5 has three regression lines with different slopes (0.23 for the $560-\mathrm{m}$ trap, 0.33 for the $760-\mathrm{m}$ trap, and 0.43 for the $960-\mathrm{m}$ trap) initially originating 
from three points and crossing nearly at a point when sediment discharges are $10^{3} \mathrm{t} / \mathrm{d}$. These distinct patterns of regression lines for each of array of sediment traps can be briefly summarized as follows: (1) T12, two closely parallel lines and one line with a larger slope, all of which cross at points very close to each other; (2) T13, three parallel lines; (3) T6, two parallel lines, and (4) T5, three straight lines with different slopes crossing at three points very close to one another. Apparently, these numerical relationships are site-dependent.

Certainly the above-mentioned correlations imply much information in terms of the supply (source), transport and then deposition (sink) of the SOT sediments, or the land-sea interaction. These are all crucial issues for resolving the sedimentary records of climate changes, because terrigenous sediment exports are governed mainly by the magnitude of rainfall. These simple numerical relationships, similar slopes or similar constants, may indicate that settling sediments in the SOT originate from the same major sources or experience similar transport processes, at least for stations \#T12, \#T13 and \#T6, when no large submarine earthquakes occur (since the earthquake-driven data have been picked out). Moreover, transport of river sediments is believed to be dominated by horizontal advection combined with gravitational settling. Hence, the regression equations enable the prediction of spatial distribution for terrigenous sediment fluxes at different river sediment discharge rates, from low $\left(10^{3} \mathrm{t} / \mathrm{d}\right)$ to normal (long-term mean, $\left.2 \times 10^{4} \mathrm{t} / \mathrm{d}\right)$ to extreme $\left(\geqslant 10^{6} \mathrm{t} / \mathrm{d}\right)$ levels. It thus allows us to resolve the question of how sediment plumes behave at different fluvial sediment discharges and to what extent the plumes disperse, although trap fluxes have not been measured in a sufficiently large area at the same time.

\subsection{Temporal and spatial variations in settling sediment fluxes derived from the empirical relationships}

Although the duration of trap measurements spanned less than 3 years and the deployment periods for the different arrays were not completely identical, the historical data on river sediment discharge can be substituted into the empirical relationships to simulate past variations of sediment mass accumulations with changing location and time. The daily Lanyang Hsi sediment discharge, used in the following calculation, was integrated by hourly river discharge multiplied by total suspended-sediment concentration, estimated by the rating-curve method (Kao and Liu, 2001; Kao et al., 2005). Data on hourly river discharge and suspended-load concentration were recorded by the Water Resources Agency of Taiwan; the data used spanned 51 years from 1950 to 2000. This enabled extrapolation of the flux data to this period. Also, the spatial distribution of sediment fluxes along a section from stations \#T12 to \#T13 to \#T6 can be used to illustrate four cases of different sediment discharge rates.

From the empirical equations, sediment fluxes were predicted at four trap stations in four cases of different sediment discharge rates, ranging from small $\left(10^{3} \mathrm{t} / \mathrm{d}\right.$, Case 1$)$ to normal $\left(2 \times 10^{4} \mathrm{t} / \mathrm{d}\right.$, Case 2) to elevated $\left(10^{5} \mathrm{t} / \mathrm{d}\right.$, Case 3$)$ rates and to flood events ( $1 \mathrm{Mt} / \mathrm{d}$, Case 4$)$, regardless of differences in components and grain sizes among the four cases, which may lead to different settling velocities and thus advective efficiencies. Results of the predicted flux are listed in Table 2. Fig. 3 depicts the horizontal variation in fluxes against distances, relative to station \#T12 (i.e. the ISR), for four arrays of traps in the four cases. Alternatively, the contour patterns of predicted fluxes were considered along the section crossing the ISR towards the central SOT for the last three cases, which were plotted manually as there were only three stations available, as seen in Fig. 4a-c. In addition, to simulate the spatial distribution of fluxes during an extreme flood event (i.e. $2 \mathrm{Mt} / \mathrm{d}$ ), a special case was also taken into account (Fig. 4d). Overall, these spatial patterns share a common feature of flux increases with increasing depth, emphasizing the significance of downslope and lateral transport for sequestering sediments to a deep basin (Heussner et al., 1999; Hsu et al., 2004; Wheatcroft and Sommerfield, 2005). Comparison of these spatial patterns reveals that the flux gradient from the slope (T12) to the trough (T6) is larger in the lower than in the higher discharge case (Figs. 3 and 4). For a given site, however, the variability of sediment flux with different levels of river delivery is higher at the remote site (e.g. station \#T6) than the proximal site (e.g. station \#T12), relative to the river mouth (Figs. 3 and 4). For instance, for station \#T6, the flux at depth $740 \mathrm{~m}(1340 \mathrm{~m})$ varies from $1.6(2.2) \mathrm{g} / \mathrm{m}^{2} / \mathrm{d}$ in Case 1 to $32(40) \mathrm{g} / \mathrm{m}^{2} / \mathrm{d}$ in Case 3-an increase by a factor of $\sim 20$ (Table 2). In contrast, for station \#T12, the flux at $770 \mathrm{~m}$ increases from 28 to $138 \mathrm{~g} /$ $\mathrm{m}^{2} / \mathrm{d}$, and for station \#T13 it changes from 11 to 
Table 2

Predicted sediment fluxes $\left(\mathrm{g} / \mathrm{m}^{2} / \mathrm{d}\right)$ in the SOT for four different daily sediment discharge rates (SDR)

\begin{tabular}{|c|c|c|c|c|c|}
\hline Trap \# & Depth (m) & $\begin{array}{l}\text { Case } 1 \\
\left(\mathrm{SDR}=10^{3} \mathrm{t} / \mathrm{d}\right)\end{array}$ & $\begin{array}{l}\text { Case } 2 \\
\left(\mathrm{SDR}=2 \times 10^{4} \mathrm{t} / \mathrm{d}\right)\end{array}$ & $\begin{array}{l}\text { Case } 3 \\
\left(\mathrm{SDR}=10^{5} \mathrm{t} / \mathrm{d}\right)\end{array}$ & $\begin{array}{l}\text { Case } 4 \\
\left(\operatorname{SDR}=10^{6} \mathrm{t} / \mathrm{d}\right)\end{array}$ \\
\hline \multirow[t]{3}{*}{ T5 } & 560 & 2.1 & 4.2 & 6.1 & 10.4 \\
\hline & 760 & 2.8 & 7.5 & 12.8 & 27.4 \\
\hline & 960 & 3.7 & 13.3 & 26.6 & 71.6 \\
\hline \multirow[t]{2}{*}{ T6 } & 740 & 1.6 & 5.9 & 11.8 & 31.8 \\
\hline & 1340 & 2.2 & 7.8 & 15.3 & 40.1 \\
\hline \multirow[t]{3}{*}{$\mathrm{T} 12$} & 570 & 5.4 & 23.4 & 51.5 & 159.1 \\
\hline & 770 & 28.2 & 56.1 & 81.3 & 138.0 \\
\hline & 970 & 34.4 & 68.6 & 99.3 & 168.6 \\
\hline \multirow[t]{3}{*}{$\mathrm{T} 13$} & 940 & 8.3 & 14.6 & 19.8 & 30.7 \\
\hline & 1140 & 15.2 & 27.7 & 38.2 & 60.5 \\
\hline & 1340 & 10.5 & 19.1 & 26.4 & 41.8 \\
\hline
\end{tabular}

$42 \mathrm{~g} / \mathrm{m}^{2} / \mathrm{d}$ at $1340 \mathrm{~m}$; both of them change by a factor of 4-5 (Table 2). This indicates that sediment burial in the central trough is very susceptible to the fluctuation in fluvial sediment contribution and also to extreme river plumes. Also, it suggests that the flood-induced flow supplies enormous amounts of pulse-like fluvial sediment into the seas and causes a broad spreading of sediments (Syvitski et al., 1998), which will be taken into consideration by integrating the sediment mass budget in certain areas, as discussed below.

Note that, as shown in Fig. $4 \mathrm{c}$ and $\mathrm{d}$, when the sediment discharge reaches a rate higher than $10^{6} \mathrm{t} / \mathrm{d}$ (i.e. $1 \mathrm{Mt} / \mathrm{d}$ ), the modeled flux in shallow water becomes gradually higher than that in deep water, which differs from the former two low-rate cases (Fig. $4 \mathrm{a}$ and b). When the discharge rate is $2 \mathrm{Mt} / \mathrm{d}$ (i.e. a catastrophic flood event), the modeled flux $\left(223 \mathrm{~g} / \mathrm{m}^{2} / \mathrm{d}\right)$ at $560 \mathrm{~m}$ increases even higher than that $\left(198 \mathrm{~g} / \mathrm{m}^{2} / \mathrm{d}\right)$ at $960 \mathrm{~m}$ (Fig. $\left.4 \mathrm{~d}\right)$. Such a pattern implies that, during storm-driven flood episodes, sediment plumes take two primary pathways in the dispersal of sediments to the SOT, namely a shallow (around $600 \mathrm{~m}$ or less) plume and a near-bottom plume (Kineke et al., 2000). Unfortunately, this modeled spatial distribution cannot be confirmed because of the absence of such a flood event, contributing sediments as high as $2 \mathrm{Mt} / \mathrm{d}$ or more, during the measurement period. More importantly, during the storm period, rough seas make in situ shipboard measurements of hydrography and suspended-sediment concentrations in the water column very difficult. Nonetheless, the modeled patterns are, to some extent, reliable, since the shallower plume seems to be attributable to the buoyancy of freshwater plumes. Because of the small amount of mixing with ambient seawater, this leads to an extensive horizontal dispersion for a river flood-induced plume associated with finegrained suspended sediments (van Maren and Hoekstra, 2005). This interpretation, however, merits further work.

With historical data on the daily Lanyang Hsi sediment discharge over a continuous period from 1950 to 2000, the formulated equations were employed to simulate the 51-year long-term settling sediment fluxes. All the obtained daily fluxes for each whole year were directly summed to yield each yearly flux. For comparison with sediment mass accumulation rate, only modeled fluxes of nearbottom traps from stations \#T13, \#T5 and \#T6 (Fig. 5), which are located at depths more representative of the SOT, are discussed below, and the flux unit is changed hereafter from $\mathrm{g} / \mathrm{m}^{2} / \mathrm{d}$ to $\mathrm{g} / \mathrm{cm}^{2} /$ $\mathrm{yr}$. The long-term variation in yearly fluxes is displayed (results of daily flux not shown); also, the long-term mean fluxes are indicated in each plot: $0.43 \mathrm{~g} / \mathrm{cm}^{2} / \mathrm{yr}$ for $\mathrm{T} 13,0.22 \mathrm{~g} / \mathrm{cm}^{2} / \mathrm{yr}$ for $\mathrm{T} 5$ and $0.13 \mathrm{~g} / \mathrm{cm}^{2} / \mathrm{yr}$ for $\mathrm{T} 6$. The predicted fluxes range from 0.24 to 0.57 for T13, from 0.06 to 0.41 for T5, and from 0.04 to $0.24 \mathrm{~g} / \mathrm{cm}^{2} / \mathrm{yr}$ for $\mathrm{T} 6$, thus reflecting that sedimentation in the central SOT is quasi-stable only, rather than relatively stable, which is usually recognized. Moreover, these temporal patterns are characterized by low flux during the middle 1970s to late 1990s and increasing flux in recent decades - this feature is particularly evident for T5 and T6 (Fig. $3 \mathrm{~b}$ and c), i.e. the central 

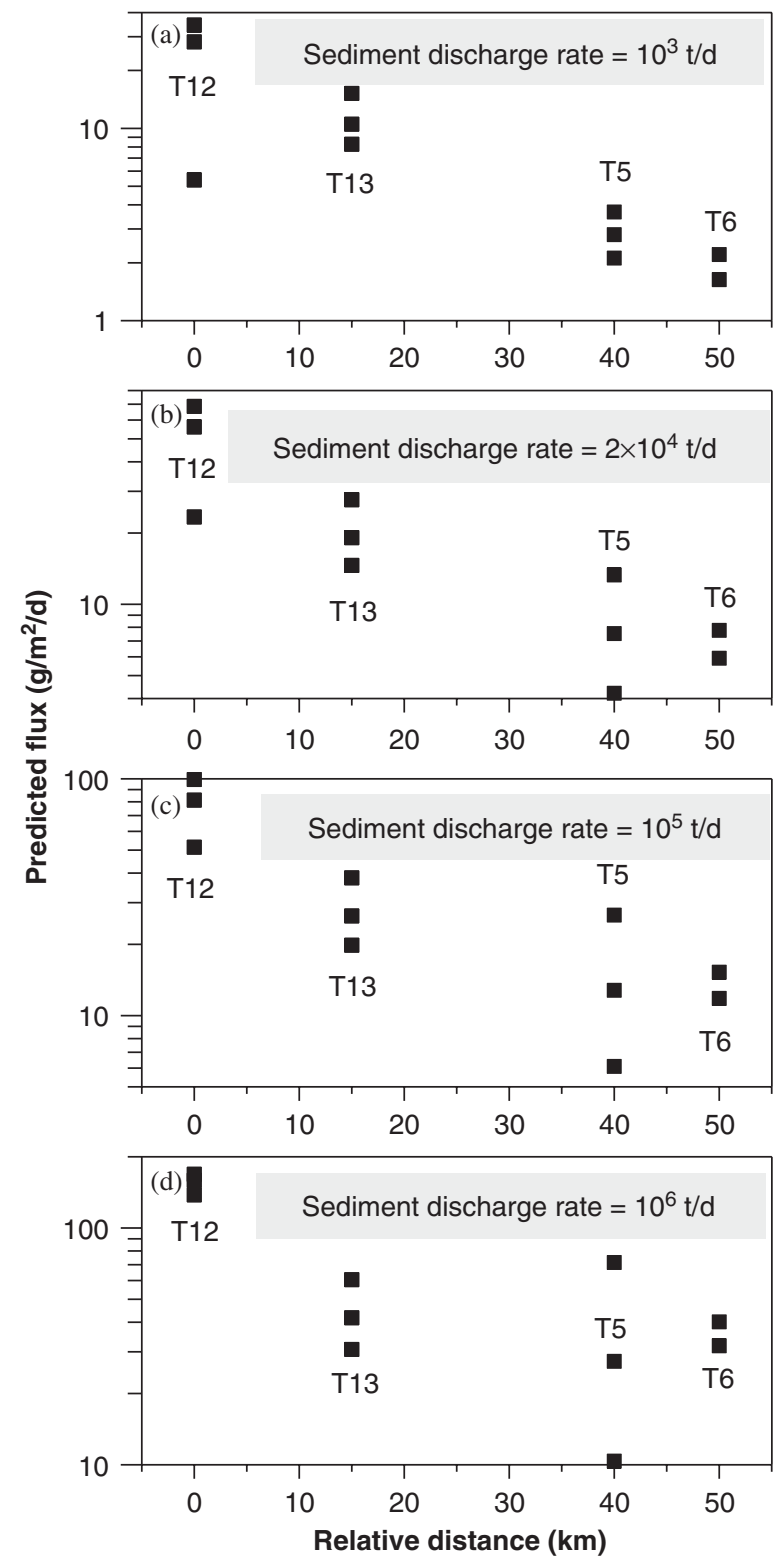

Fig. 3. Horizontal variations in predicted flux $\left(\mathrm{g} / \mathrm{m}^{2} / \mathrm{d}\right)$ for four arrays of sediment traps against relative distance to station \#T12, near the Ilan Shelf and Ridge. A total of four cases for different sediment discharge rates are shown.

SOT. Fluxes have tended to increase greatly since 1988, suggestive of a correlation, at least in part, with the gradually increasing rainfall in recent decades (Liu et al., 2002; Dadson et al., 2003). The results imply the potential of unambiguously unraveling past climate change through sedimentary records of fluvial influxes once a suitable sediment core is available.

\subsection{Implication for climate changes and sedimentation}

Usually, the magnitude of terrigenous sediment fluxes into the seas is strongly dependent on riverine sediment exports, and riverine suspended loads are a function of precipitation, which is always enhanced by storm or flood events. The facts have been well documented (Milliman and Syvitski, 1992; Mulder and Syvitski, 1995; Inman and Jenkins, 1999). Accordingly, to examine the significance of flood-driven sediment supply, the flood-induced contribution over the 51-year period was estimated. From 1950 to 2000 there were 212 days when the river discharge was higher than $500 \mathrm{~cm}^{3} / \mathrm{s}$, approximately 20 times or more higher than the normal discharge of $\sim 20 \mathrm{~cm}^{3} / \mathrm{s}$, for the Lanyang Hsi (Kao and Liu, 2001, 2002), which was arbitrarily defined as a flood event in the modeled period. The derived proportions of flood-induced contributions during the 51 -year period are $3.3 \%$ for $\mathrm{T} 13,11 \%$ for $\mathrm{T} 5$ and $10 \%$ for T6, although the flood-occurring time (212 days) accounts for only $1.14 \%$ of 51 years. This indicates again that the central part of the SOT (e.g. stations \#T5 and \#T6) is more sensitive to floodinduced sediment supply than the slope bottom (e.g. station \#T13) and is, hence, a good location for the preservation of high-resolution climatic signatures regarding rainfall.

We compared the predicted long-term mean seabed fluxes (represented by the near-bottom traps) at three sites in the central SOT (i.e. highsedimentation spot), as given in Fig. $4\left(0.43 \mathrm{~g} / \mathrm{cm}^{2} /\right.$ yr for station \#T13, $0.22 \mathrm{~g} / \mathrm{cm}^{2} / \mathrm{yr}$ for station \#T5, and $0.13 \mathrm{~g} / \mathrm{cm}^{2} / \mathrm{yr}$ for station \#T6), with sediment mass accumulation rates measured at three selected sites neighboring the three trap sites, as summarized in Table 3. Similar investigations were performed by Sommerfield and Nittrouer (1999) and Wheatcroft and Sommerfield (2005). As a result, the predicted values are somewhat lower than the ${ }^{210} \mathrm{~Pb}$-derived values reported by Chung and Chang (1995), but more consistent with the ${ }^{137} \mathrm{Cs}$-derived values reported by Lee et al. (2004). Furthermore, the sediment mass budget was integrated within this high rate area of $\sim 2000 \mathrm{~km}^{2}$ for a mean deposition rate of $0.26 \mathrm{~g} / \mathrm{cm}^{2} / \mathrm{yr}$ (average of $0.43,0.22$ and $0.13 \mathrm{~g} / \mathrm{cm}^{2} / \mathrm{yr}$ ). The derived mass burial is $5.2 \mathrm{Mt} / \mathrm{yr}$, representing $80 \%$ of the Lanyang Hsi delivery. This categorically demonstrates the SOT as serving as an effective receptacle of fluvial sediments from the Lanyang Hsi. 


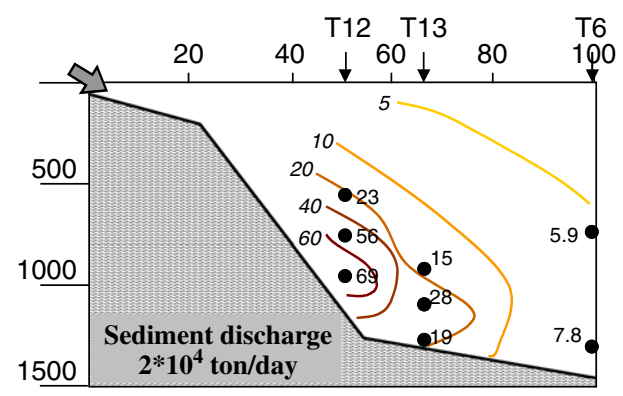

(a)

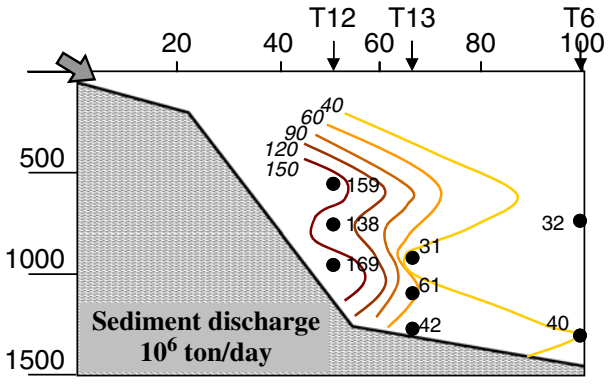

(c)

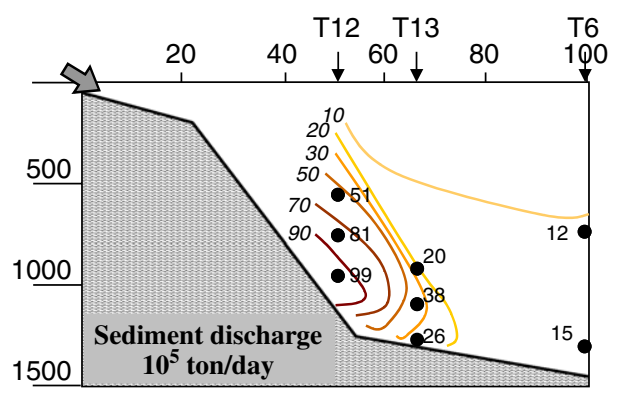

(b)

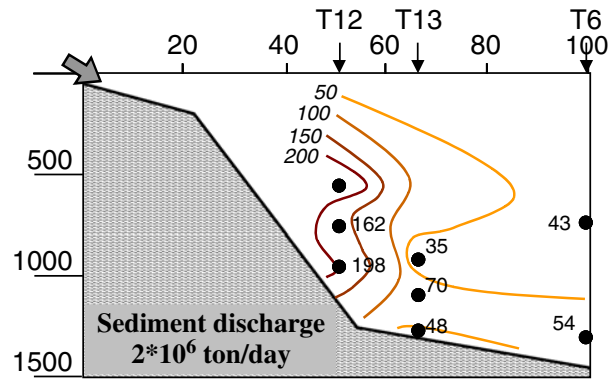

(d)

Fig. 4. Contour plots of predicted sediment flux $\left(\mathrm{g} / \mathrm{m}^{2} / \mathrm{d}\right)$ at four different daily sediment discharge rates along a section from the Ilan Shelf and Ridge to the SOT, including three trap stations (i.e. \#T12, \#T13 and \#T6), which are presented as the location relative to the Lanyang Hsi river mouth (indicated by arrows). Note that contour intervals are not constant; also, flux data are labeled.

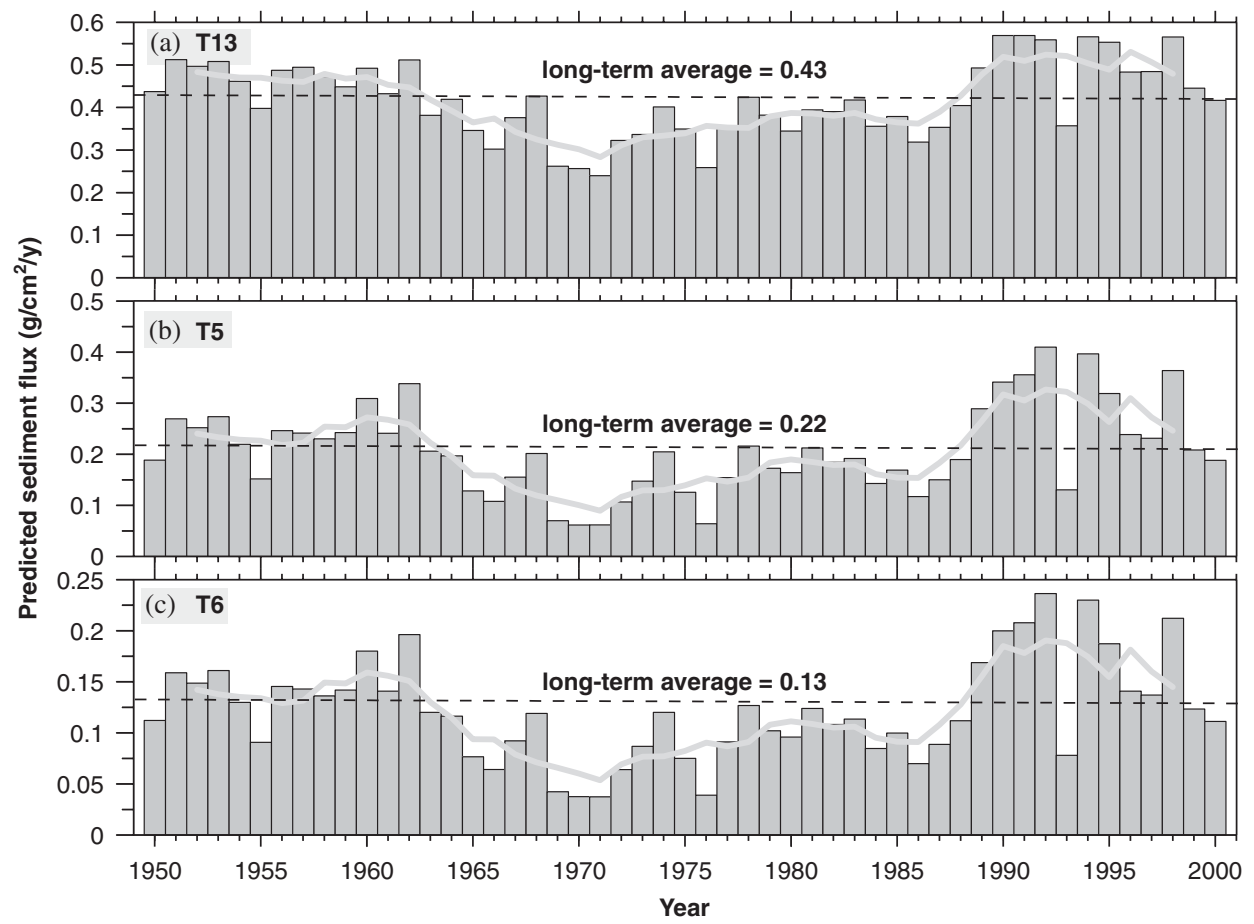

Fig. 5. Temporal variations in predicted fluxes $\left(\mathrm{g} / \mathrm{cm}^{2} / \mathrm{yr}\right)$ for three near-bottom traps in the SOT (i.e. T13-1140 $\mathrm{m}$, T5 - $970 \mathrm{~m}$, and T6 $1340 \mathrm{~m}$ ) from 1950 to 2000. Running average curves with a running width of $n=5$ and long-term means (indicated by dashed lines) are also shown. 
Table 3

Comparison of the long-term mean settling fluxes predicted from three near-bottom traps with nearby sediment mass accumulation rates (MAR) derived from ${ }^{210} \mathrm{~Pb}$ and ${ }^{137} \mathrm{Cs}$ chronology (Chung and Chang, 1995; Lee et al., 2004) (locations for the traps are indicated in Fig. 1. Also, sedimentation rates are shown here)

\begin{tabular}{|c|c|c|c|c|c|c|c|}
\hline \multicolumn{2}{|c|}{$\begin{array}{l}\text { Sediment trap (predicted long- } \\
\text { term mean) })^{\mathrm{a}}\end{array}$} & \multicolumn{3}{|c|}{ Sediment core $\left({ }^{210} \mathrm{~Pb}\right)^{\mathrm{b}}$} & \multicolumn{3}{|c|}{ Sediment core $\left({ }^{210} \mathrm{~Pb} /{ }^{137} \mathrm{Cs}\right)^{\mathrm{c}}$} \\
\hline Location & $\begin{array}{l}\text { Settling flux } \\
\left(\mathrm{g} / \mathrm{cm}^{2} / \mathrm{yr}\right)\end{array}$ & Location & $\mathrm{SR}(\mathrm{cm} / \mathrm{yr})$ & $\begin{array}{l}\operatorname{MAR}(\mathrm{g} / \\
\left.\mathrm{cm}^{2} / \mathrm{yr}\right)\end{array}$ & Location & $\mathrm{SR}(\mathrm{cm} / \mathrm{yr})$ & $\begin{array}{l}\operatorname{MAR}\left(\mathrm{g} / \mathrm{cm}^{2} /\right. \\
\mathrm{yr})\end{array}$ \\
\hline $\begin{array}{l}\mathrm{T} 13 \\
24^{\circ} 55.36^{\prime} \mathrm{N}, \\
122^{\circ} 19.57^{\prime} \mathrm{E} \\
(1392 \mathrm{~m})\end{array}$ & 0.43 & $\begin{array}{l}\mathrm{C} 1 \\
25^{\circ} 00.19^{\prime} \mathrm{N}, \\
122^{\circ} 20.48^{\prime} \mathrm{E} \\
(1187 \mathrm{~m})\end{array}$ & 0.52 & 0.421 & $\begin{array}{l}\mathrm{L} 1 \\
24^{\circ} 48.43^{\prime} \mathrm{N}, \\
122^{\circ} 30.30^{\prime} \mathrm{E} \\
(1279 \mathrm{~m})\end{array}$ & $0.44 / 0.37$ & $0.35 / 0.26$ \\
\hline $\begin{array}{l}\text { T5 } \\
25^{\circ} 06.45^{\prime} \mathrm{N}, \\
122^{\circ} 30.06^{\prime} \mathrm{E} \\
(1060 \mathrm{~m})\end{array}$ & 0.22 & $\begin{array}{l}\mathrm{C} 2 \\
25^{\circ} 11.35^{\prime} \mathrm{N}, \\
122^{\circ} 30.88^{\prime} \mathrm{E} \\
(894 \mathrm{~m})\end{array}$ & 0.37 & 0.355 & $\begin{array}{l}\mathrm{L} 2 \\
25^{\circ} 10.03^{\prime} \mathrm{N}, \\
122^{\circ} 40.03^{\prime} \mathrm{E} \\
(1282 \mathrm{~m})\end{array}$ & $0.24 / 0.20$ & $0.20 / 0.15$ \\
\hline $\begin{array}{l}\mathrm{T} 6 \\
24^{\circ} 59.63^{\prime} \mathrm{N}, \\
122^{\circ} 39.26^{\prime} \mathrm{E} \\
(1440 \mathrm{~m})\end{array}$ & 0.13 & $\begin{array}{l}\mathrm{C} 3 \\
24^{\circ} 59.44^{\prime} \mathrm{N}, \\
122^{\circ} 40.24^{\prime} \mathrm{E} \\
(1465 \mathrm{~m})\end{array}$ & 0.25 & 0.205 & $\begin{array}{l}\mathrm{L} 3 \\
25^{\circ} 00.10^{\prime} \mathrm{N}, \\
122^{\circ} 40.07^{\prime} \mathrm{E} \\
(1474 \mathrm{~m})\end{array}$ & $0.19 / 0.19$ & $0.13 / 0.12$ \\
\hline
\end{tabular}

${ }^{\mathrm{a}}$ This work.

${ }^{\mathrm{b}}$ Chung and Chang (1995).

${ }^{\mathrm{c}}$ Lee et al. (2004).

Moreover, the question is raised as to what extent an extreme flood-induced plume may spread, although no shipboard measurements can prove such a case. Given that the sediment discharge rate is $2 \mathrm{Mt} / \mathrm{d}$, a half (i.e. $1 \mathrm{Mt}$ ) is assumed to be effectively carried offshore to the SOT or beyond by the prevailing northward Kuroshio, because the suspended load is predominately fine particles (silt and clay). Thus, the area where the sediment plume may disperse can be simulated. A representative flux in the SOT was roughly estimated by averaging the three predicted fluxes at near-bottom depths, arriving at $49 \mathrm{~g} / \mathrm{m}^{2} / \mathrm{d}$, as predicted in Case 4 . The expected dispersal area was estimated to be $\sim 20,000 \mathrm{~km}^{2}$; the spreading extent can approach $124.5^{\circ} \mathrm{E}$ or beyond. However, because of the possible overestimation of the mean seabed flux used and the fact that the Kuroshio probably prevents sediment transport toward its eastern boundary (Hsu et al., 1998), it is inferred that the advective extent is possibly more northward than expected and is confined principally to the western boundary of the Kuroshio. Accordingly, it is hypothesized that flood-induced suspended sediments from northern Taiwan can be transported long distances to approximately $125^{\circ} \mathrm{E}$ or beyond; however, this merits further work.

\section{Concluding remarks}

Data on terrigenous sediment fluxes observed from the SOT and fluvial sediment discharge from eastern Taiwan were refined in this study. A striking finding is the very close relationship between them. As a result, regression equations could be used to simulate the temporal and spatial variability in sediment fluxes over longtime scales (i.e. up to 51 years of hydrological data), clarifying the relationship between riverine suspended supply and deposition rate. From a long-term perspective, the predicted pattern is apparently consistent with the observed distribution. Also, it has promoted a better understanding of the transport process of floodinduced sediment plumes. In addition, it may shed light on the reconstruction of past climate changes, relevant to precipitation, qualitatively and quantitatively, if a suitable core could be obtained. In particular, this implies the possibility of exploring historical disaster flood events from sedimentary records of the SOT. In addition, a higher time resolution (i.e. 2-3 day intervals) of trap measurements from the SOT would allow the elucidation of transport processes and sediment fate in detail. This is important for retrieving information on climatic and environmental changes from sediment coring 
from the SOT, where sediment deposition is very sensitive to the fluctuation in fluvial contributions and is enhanced by flood events. This is the first study to quantitatively link riverine sediment discharge (i.e. river runoff and rainfall) at normal to extreme levels with terrigenous sediment deposition.

\section{Acknowledgments}

We are grateful to two anonymous reviewers for their constructive comments. We thank the technicians and crew of R/V Ocean Researcher I for their help with sampling. Thanks are also extended to Dr. G.W. Hung and K. Huang for pretreatment of samples.

\section{References}

Chakrapani, G.J., 2005. Factors controlling variations in river sediment loads. Current Science 88, 569-575.

Chung, Y., Chang, W.C., 1995. Pb-210 fluxes and sedimentation rates on the lower continental slope between Taiwan and the south Okinawa Trough. Continental Shelf Research 15, 149-164.

Chung, Y., Hung, K.W., 2000. Particulate fluxes and transport on the slope between the southern East China Sea and the South Okinawa Trough. Continental Shelf Research 20, 571-597.

Chung, Y., Chung, K., Chang, H.C., Wang, L.W., Yu, C.M., Hung, G.W., 2003. Variabilities of particulate flux and Pb-210 in the southern East China Sea and western South Okinawa Trough. Deep-Sea Research II 50, 1163-1178.

Dadson, S.J., Hovius, N., Chen, H., Dade, W.B., Hsieh, M.L., Willett, S.D., Hu, J.C., Horng, M.J., Chen, M.C., Stark, C.P., Lague, D., Lin, J.C., 2003. Links between erosion, runoff variability and seismicity in the Taiwan orogen. Nature 426, 648-651.

Heussner, S., De Madron, X.D., Radakovitch, O., Beaufort, L., Biscaye, P.E., Carbonne, J., Delsaut, N., Etcheber, H., Monaco, A., 1999. Spatial and temporal patterns of downward particle fluxes on the continental slope of the Bay of Biscay (northeastern Atlantic). Deep-Sea Research II 46, 2101-2146.

Hsu, S.C., 1998. Sources and transport of sediments and trace metal geochemistry in the water column off northeastern Taiwan. Ph.D. Thesis, Institute of Oceanography, National Taiwan University, 268pp. (in Chinese with English abstract).

Hsu, S.C., Lin, F.J., Jeng, W.L., Tang, T.Y., 1998. The effect of a cyclonic eddy on the distribution of lithogenic particles in the southern East China Sea. Journal Marine Research 56, $813-832$.

Hsu, S.C., Lin, F.J., Jeng, W.L., Chung, Y., Shaw, L.M., 2003. Hydrothermal signatures in the southern Okinawa Trough detected by the sequential extraction of settling particles. Marine Chemistry 84, 49-66.

Hsu, S.C., Lin, F.J., Jeng, W.L., Chung, Y., Shaw, L.M., Hung, K.W., 2004. Observed sediment fluxes of the southwesternmost Okinawa Trough enhanced by episodic events: flood runoff from northeastern Taiwan river and great earthquakes. Deep-Sea Research I 51, 979-997.

Huh, C.A., Su, C.C., Liang, W.Z., Ling, C.Y., 2004. Linkages between turbidites in the southern Okinawa Trough and submarine earthquakes. Geophysical Research Letters 31, L12304.

Hung, J.J., Lin, C.S., Chung, Y.C., Hung, G.W., Liu, W.S., 2003. Lateral fluxes of biogenic particles through the Mien-Hua canyon in the southern East China Sea slope. Continental Shelf Research 23, 935-955.

Inman, D.L., Jenkins, S.A., 1999. Climate change and the episodicity of sediment flux of small California rivers. Journal of Geology 107, 251-270.

Jeng, W.L., Lin, S., Kao, S.J., 2003. Distribution of terrigenous lipids in marine sediments off northeastern Taiwan. Deep-Sea Research II 50, 1179-1201.

Kao, S.J., Liu, K.K., 2001. Estimating the suspended sediment load by using the historical hydrometric record from the Lanyang-Hsi watershed. Terrestrial, Atmospheric and Oceanic Sciences 12, 401-414.

Kao, S.J., Liu, K.K., 2002. Exacerbation of erosion induced by human perturbation in a typical Oceania watershed: insight from 45 years of hydrological records from the Lanyang-Hsi River, northeastern Taiwan. Global Biogeochemical Cycles 16.

Kao, S.J., Lee, T.Y., Milliman, J.D., 2005. Calculating highly fluctuated suspended sediment fluxes from mountainous rivers in Taiwan. Terrestrial, Atmospheric and Oceanic Sciences 16, 641-663.

Kineke, G.C., Woolfe, K.J., Kuehl, S.A., Milliman, J.D., Dellapenna, T.M., Purdon, R.G., 2000. Sediment export from the Sepik River, Papua New Guinea: evidence for a divergent sediment plume. Continental Shelf Research 20, 2239-2266.

Lee, S.Y., Huh, C.A., Su, C.C., You, C.F., 2004. Sedimentation in the Southern Okinawa Trough: enhanced particle scavenging and teleconnection between the Equatorial Pacific and western Pacific margins. Deep Sea Research-I 51, $1769-1780$.

Liu, S.C., Wang, C.H., Shiu, C.J., Chang, H.W., Hsiao, C.K., Liaw, S.H., 2002. Reduction in sunshine duration over Taiwan: causes and implications. Terrestrial, Atmospheric and Oceanic Sciences 13, 523-545.

Milliman, J.D., Kao, S.J., 2005. Hyperpycnal discharge of fluvial sediment to the ocean: impact of Super-typhoon Herb (1996) on Taiwanese Rivers. Journal of Geology 113, 503-516.

Milliman, J.D., Syvitski, J.P.M., 1992. Geomorphic tectonic control of sediment discharge to the ocean - the importance of small mountainous rivers. Journal of Geology 100, 525-544.

Mulder, T., Syvitski, J.P.M., 1995. Turbidity currents generated at river mouths during exceptional discharges to the world oceans. Journal of Geology 103, 285-299.

Mulder, T., Syvitski, J.P.M., 1996. Climatic and morphologic relationships of rivers: implications of sea-level fluctuations on river loads. Journal of Geology 104, 509-523.

Mulder, T., Migeon, S., Savoye, B., Jouanneau, J.M., 2001. Twentieth century floods recorded in the deep Mediterranean sediments. Geology 11, 1011-1014.

Mulder, T., Syvitski, J.P.M., Migeon, S., Faugères, J.C., Savoye, B., 2003. Marine hyperpycnal flows: initiation, behavior and 
related deposits. A review. Marine and Petroleum Geology 20, 861-882.

Perissoratis, C., Papadopoulos, G., 1999. Sediment instability and slumping in the southern Aegean Sea and the case history of 1956 tsunami. Marine Geology 161, 287-305.

Schimmelmann, A., Zhao, M., Harvey, C.C., Lange, C.B., 1998. A large California flood and correlative global climatic events 400 years ago. Quaternary Research 49, 51-61.

Sommerfield, C.K., Nittrouer, C.A., 1999. Modern accumulation rates and a sediment budget for the Eel shelf: a flooddominated depositional environment. Marine Geology 154, 227-241.

St-Onge, G., Mulder, T., Piper, D.J.W., Hillaire-Marcel, C., Stoner, J.S., 2004. Earthquake and flood-induced turbidites in the Saguenay Fjord (Quèbec): a Holocene paleoseismicity record. Quaternary Science Reviews 23, 283-294.
Syvitski, J.P.M., Skene, K.I., Nicholson, M.K., Morehead, M.D., 1998. Plume1.1: deposition of sediment from a fluvial plume. Computers and Geosciences 24, 159-171.

Syvitski, J.P.M., Kettner, A.J., Peckham, S.D., Kao, S.J., 2005. Predicting the flux of sediment to the coastal zone: application to the Lanyang watershed, northern Taiwan. Journal of Coastal Research 21, 580-587.

van Maren, D.S., Hoekstra, P., 2005. Dispersal of suspended sediments in the turbid and highly stratified Red River plume. Continental Shelf Research 25, 503-519.

Water Resources Bureau, 1997. Hydrological Year Book of Taiwan, Republic of China, 1995, Ministry of Economic Affairs, Taipei, Taiwan, ROC, 399pp.

Wheatcroft, R.A., Sommerfield, C.K., 2005. River sediment flux and shelf sediment accumulation rates on the Pacific Northwest margin. Continental Shelf Research 25, 311-332. 